\title{
Discussion of Optimized Operation of a nearly Zero Energy Building's Energy System in China
}

\begin{abstract}
A nearly zero energy office building was established in north China as a demonstration project to explore the nearly zero energy building's technical system in China. Not only the building itself, but also the energy system was designed with careful consideration to satisfy its high positioning and experimental verification attributes. Energy system in this building is completely finished and extremely challenging. Two kinds of renewable energy system worked together to serve the building, as operation modes varied accordingly to outside weather conditions. Depending on different system combinations, 4 strategies were found, and in this article, 4 of them are discussed. Energy consumption and system performance were compared and analysed to find an optimized operation.
\end{abstract}

\section{Introduction}

A 4-floor office building is constructed as a Nearly Zero Energy demo building in north China, addressing fundamental issues about the building's energy efficiency. Not only the building itself, but also the energy system was designed with careful consideration to satisfy its high positioning and experimental verification attributes.

The envelope of the building has much better thermal insulation to reduce the cooling and heating demand compared to the current building standard in China. 25 $\mathrm{mm}$ of vacuum insulation board with thermal conductivity of $0.004 \mathrm{~W} /\left(\mathrm{m}^{2} \cdot \mathrm{K}\right)$ was used for external wall. The window has a $\mathrm{K}$ value of $1.2 \mathrm{~W} /\left(\mathrm{m}^{2} \cdot \mathrm{K}\right)$, which uses vacuum glass and internal electrical shading device. The roof of the building uses $200 \mathrm{~mm}$ of expanded Polystyrene (EPS) with thermal conductivity of 0.03 $\mathrm{W} /\left(\mathrm{m}^{2} \cdot \mathrm{K}\right)$.

Table 1. Nomenclature.

\begin{tabular}{|c|c|}
\hline Nomenclature & Description \\
\hline $\begin{array}{c}\text { Absorption } \\
\text { Chiller }\end{array}$ & $\mathrm{AC}$ \\
\hline $\mathrm{E}_{\mathrm{HP} 1}$ & Energy consumption of HP1 \\
\hline ЕPHP1-1 & $\begin{array}{l}\text { Energy consumption of HP1 primary } \\
\text { side circulation pump }\end{array}$ \\
\hline EPHP1-2 & $\begin{array}{l}\text { Energy consumption of HP1 } \\
\text { secondary side circulation pump }\end{array}$ \\
\hline $\mathrm{E}_{\mathrm{HP} 2}$ & Energy consumption of HP2 \\
\hline ЕРHP2-1 & $\begin{array}{l}\text { Energy consumption of HP2 primary } \\
\text { side circulation pump }\end{array}$ \\
\hline ЕРHP2-2 & $\begin{array}{c}\text { Energy consumption of HP2 } \\
\text { secondary side circulation pump }\end{array}$ \\
\hline $\mathrm{E}_{\mathrm{AC}}$ & $\begin{array}{l}\text { Energy consumption of Absorption } \\
\text { Chiller }\end{array}$ \\
\hline EPAC-1 & $\begin{array}{l}\text { Energy consumption of AC primary } \\
\text { side circulation pump }\end{array}$ \\
\hline EPAC-2 & $\begin{array}{l}\text { Energy consumption of AC primary } \\
\text { side circulation pump }\end{array}$ \\
\hline EPAC-3 & Energy consumption of AC hot water \\
\hline
\end{tabular}

\begin{tabular}{|c|c|}
\hline EPWT-1 & $\begin{array}{l}\text { side circulation pump } \\
\text { Energy consumption of water tank } \\
\text { cold storage side circulation pump }\end{array}$ \\
\hline EPWT-2 & $\begin{array}{l}\text { Energy consumption of cold supply } \\
\text { circulation pump }\end{array}$ \\
\hline $\begin{array}{l}\mathrm{T}_{\text {2out }} \\
\mathrm{T}_{2 \text { in }}\end{array}$ & $\begin{array}{l}\text { outlet of } \mathrm{HP} / \text { Chiller secondary side } \\
\text { inlet of } \mathrm{HP} / \text { Chiller secondary side }\end{array}$ \\
\hline
\end{tabular}

\section{Energy System ${ }^{[1-3]}$}

Under the increasingly severe problem of energy shortage and environmental pollution, renewable energy plays more important roles as buildings' energy system, especially in low energy buildings.

Ground source heat pump has been successfully applied in different projects in China. Due to its relatively high performance and positive environmental effects, it is recognized as one of best options in areas of balanced heating and cooling demands. Solar energy has been widely used in buildings by solar thermal and PV panel in China, especially in regions of high solar radiation.

Due to the above consideration, the combined solarthermal and ground source heat pump system was determined as the final choice of the energy system.

The diagram of the energy system is shown in figure 1 . The absorption chiller, driven by hot water from solar collection systems, processes the ventilation load of the $1^{\text {st }}$ and $4^{\text {th }}$ floor in summer, is supplemented by a $50 \mathrm{~kW}$ GSHP unit (GSHP 1\#). In winter, absorption chiller out of work and GSHP 1 \# provides ventilation load of the $1^{\text {st }}$ and $4^{\text {th }}$ floor. The other $100 \mathrm{~kW}$ GSHP unit (GSHP 2\#) is in place to meet both heating and cooling demands for the $2^{\text {nd }}$ and $3^{\text {rd }}$ floor in the whole year. Cooperating with ground source heat pump, solar collection systems provide direct heating in winter with thermal storage. A hot water tank is installed to store thermal energy in the form of hot water.

Since the building is the first nearly zero energy building, there are some consideration in energy system design

\footnotetext{
*Huai Li: lihuai027@qqq.com
} 
and equipment capacity choice. Though each equipment and system has certain terminal connection from the original design, due to the low building cooling and heating load, energy system and equipment have the possibility to connect with different floor terminal.

GSHP1 and GSHP2 units, the absorption chiller, provide fresh air load for the $1^{\text {st }}$ and $4^{\text {th }}$ floor and the cooling load for the $2^{\text {nd }}$ and $3^{\text {rd }}$ floor. The space cooling/heating of the $1^{\text {st }}$ and $4^{\text {th }}$ floor is provided by other systems. This article discussed the system operation in cooling season only.

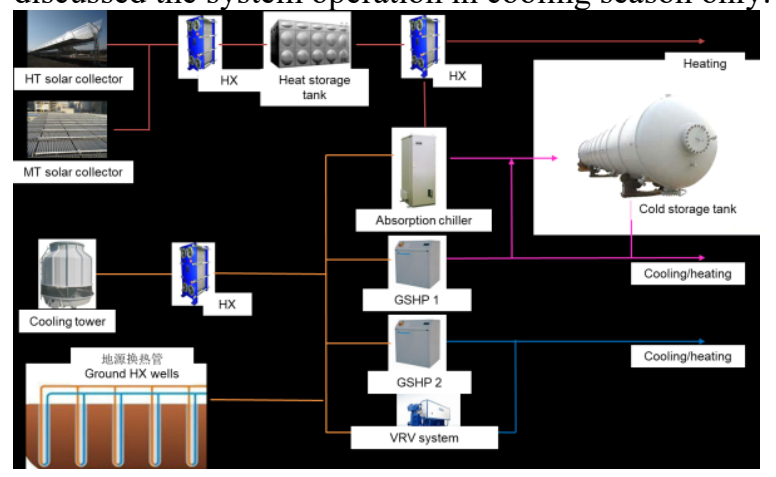

Fig. 1. Logical diagram of the energy system GSHP1, GSHP2, absorption chiller and their variable combination for the building cooling in summer season as discussed mainly in the article. System performance and energy consumption were compared.

Operation of the energy system was monitored, carefully tested and analysed, either the energy consumption or the system performance to verify and testy the original system design and experimental target.

\section{Operation Strategy}

The major principle of the energy system operation is: the solar thermal operates first, then the ground source heat pump system works as an assist. In the original design, the absorption chiller provides the $1^{\text {st }}$ and $4^{\text {th }}$ floor fresh air, that GSHP1 system works as an assist when absorption chiller is out of work, while GSHP 2 works mainly for the $2^{\text {nd }}$ and $3^{\text {rd }}$ floor.

Since the building is designed as nearly zero energy building, maximum building heating or cooling load is much lower than normal buildings and the building load is not sensitive to outside weather condition. It is why the building energy system could easily switched to service different terminal systems. As the system operation continues, multiple operation modes and energy saving potential were found and all the possible system combination and operation strategies are listed in Table 1.

Table 1. Operation modes

\begin{tabular}{|c|c|}
\hline Strategy & contents \\
\hline 1 & $\mathrm{HP} 1+\mathrm{HP} 2$ \\
\hline 2 & $\mathrm{AC}+\mathrm{HP} 2$ \\
\hline 3 & $\mathrm{AC}+\mathrm{HP} 1$ \\
\hline 4 & $\mathrm{AC}+\mathrm{HP} 1+\mathrm{HP} 2$ \\
\hline
\end{tabular}

The hot water temperature from the water tank was the decision making between different strategies. For example, when the hot water temperature above $80^{\circ} \mathrm{C}$, then the system works in strategy2. while, when the hot water temperature is lower than $80^{\circ} \mathrm{C}$, strategy 1 works. Strategy 3 and 4 are newly founded working modes with the operation continues.

In the following sections, the article describes different strategies of the system performance. Energy saving is calculated, as it is expected to be chosen out of the best working strategy of the system. Operation data of year 2018 in different mode was discussed into great extent.

\section{Discussion of Different Strategies}

System operated at four strategies (1 to 4 ) in summer season of 2018. In the following sections, we concentrate on the discussion of these strategies. By calculating system energy consumptions and system daily performance, the article compares the energy consumption and operation effects. Different outside weather condition leads to different indoor cooling load requirement which decides the energy system operation strategy.

\section{1 weather condition}

Ambient humidity from 8:00 to 18:00 in the whole summer season were plotted in Figure 2. It is found from the figure that in June and September, air humidity is about 10, and in mid-July and August humidity is close to $20 \mathrm{~g} / \mathrm{kg}$. It is high temperature and humidity weather.

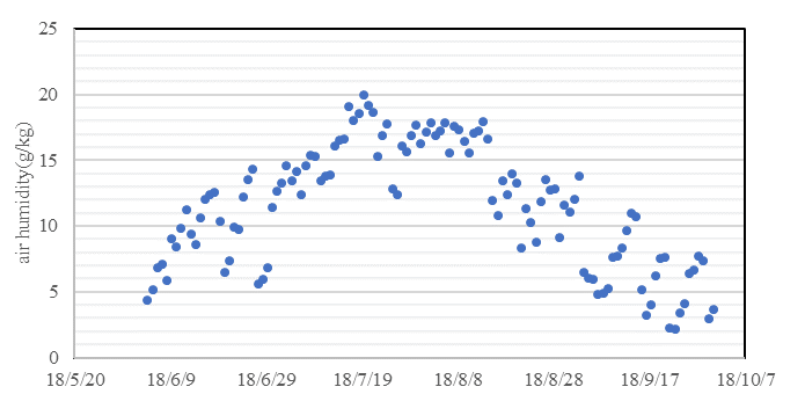

Fig. 2 Outside air humidity in summer season of 2018

\subsection{Strategy 1}

Strategy 1 here indicates that GSHP1 and absorption chiller function together for the building cooling. GSHP1 system serves in the $3^{\text {rd }}$ floor room cooling and fresh air system, while absorption chiller provides fresh air load for the $1^{\text {st }}, 4^{\text {th }}$ floor and $2^{\text {nd }}$ floor. The following data is the system operation on $1^{\text {st }}$ June, in which inlet and outlet water temperature of absorption chiller and GSHP system were discussed and COP was analyzed. The weather condition and the operation performance of the systems are shown in the following figures and the energy consumption is shown in table 2 .

Gray, orange and blue lines in figure 3 show the variation of inlet and outlet water temperature and water 
flow rate of GSHP1 on the evaporating side, while the yellow points are the calculated COP. Since the system provides fresh air load and the outside temperature is not very high, the inlet and outlet water temperature is around 16.8 and $16.9{ }^{\circ} \mathrm{C}$ respectively, and the average COP is around 5.6 before 12:00, while it increases to 8 in the afternoon.

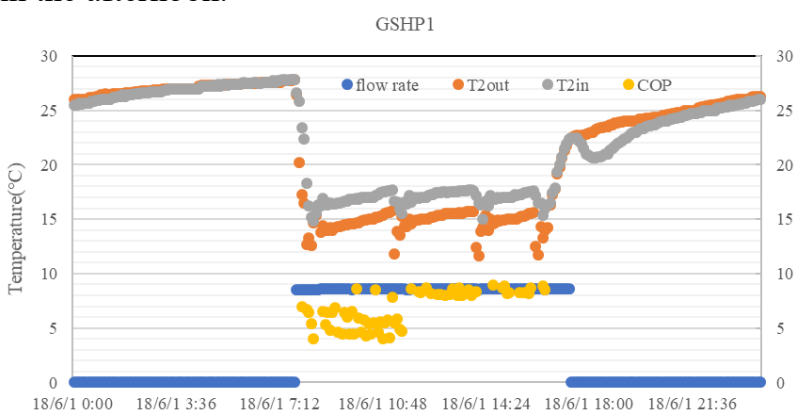

Fig. 3 Daily operation of GSHP1 on June $1^{\text {st }}$

Same as figure 3, gray, orange and blue lines in figure 4 show the variation of inlet, outlet water temperature and water flow rate of absorption chiller. The system provides room and fresh air load for the 3rd floor, in which the inlet and outlet temperature is around 10.3 and $13.9{ }^{\circ} \mathrm{C}$ respectively, while the average temperature difference is around $3.6^{\circ} \mathrm{C}$. The same applies to GSHP1, in which the daily COP of the unit is around 0.65 , which seems relatively steady before 12:00, but it dispersed after that time.

Since the building has excellent envelop isolation, room load is not sensitively related to the outside weather variation. After half days' operation, room temperature reaches the setting point, as the room cooling load varies slowly and lags behind the weather variation. With the reduction of room cooling load, heat pump works in an intermittent mode, which might cause the unsteady system work.

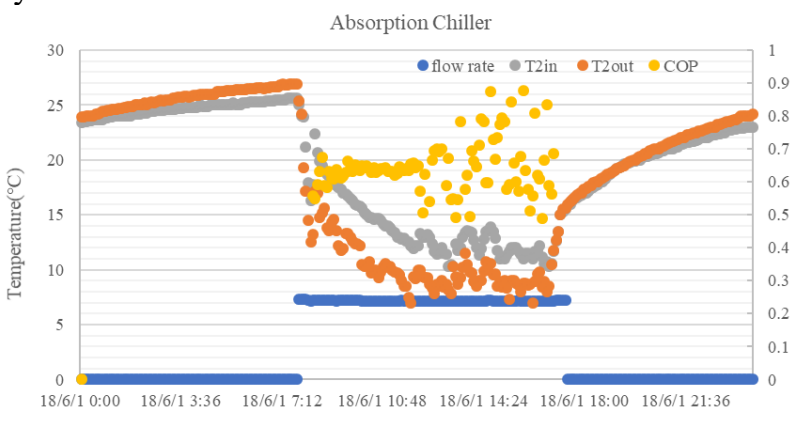

Fig. 4 Daily operation of absorption chiller on June $1^{\text {st }}$

Table 2. Energy consumption in Strategy 1

\begin{tabular}{|c|l|l|}
\hline No. & $\begin{array}{l}\text { Energy Consumption } \\
\text { Description }\end{array}$ & $\begin{array}{l}\text { Energy } \\
\text { Consumption } \\
(\mathrm{kWh})\end{array}$ \\
\hline GSHP1 & EHP1+EPHP1-1 + EPHP1-2 & 53.17 \\
\hline AC & EAC+EPAC-1+EPAC-2+EPAC-3 & 38.47 \\
\hline
\end{tabular}

\subsection{Strategy 2}

In Strategy 2, GSHP1 works in mode 1 and GSHP2 works in mode 2 . System operation on July $10^{\text {th }}$ is selected to be analysed. Daily heat pump operation is shown in figure 5 and 6 . Inlet and outlet water temperature of heat pump 1 was around 11.4 and $14.3^{\circ} \mathrm{C}$ respectively, revealing a temperature difference of about $3^{\circ} \mathrm{C}$, while the daily COP is around 5.7. The heat pump functions relatively steady to the COP variation, but the outlet water temperature varies at two values, which could be avoided if the system operates under water volume variable to obtain better COP.

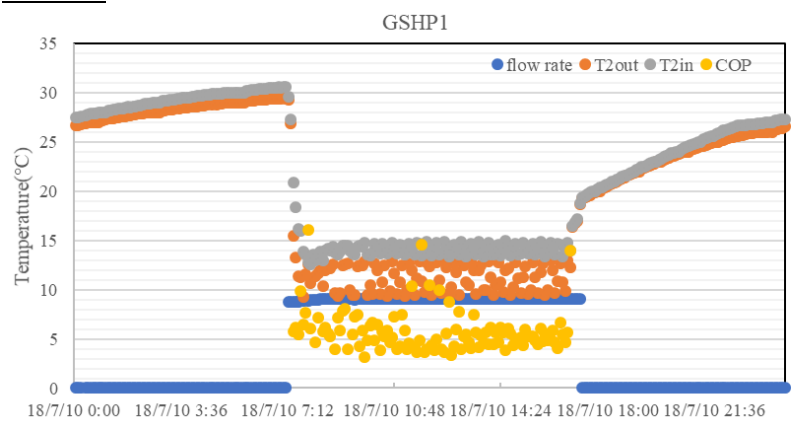

Fig. 5 Daily operation of GSHP1 on July $10^{\text {th }}$ Inlet and outlet water temperature of heat pump 2 is shown in figure 6 , and inlet and outlet water temperature are around 12.7 and 15.8, which the daily COP is around 6.2 , which works very steadily. System energy consumption in this strategy is shown in table 3 and $181.98 \mathrm{kWh}$ was consumed.

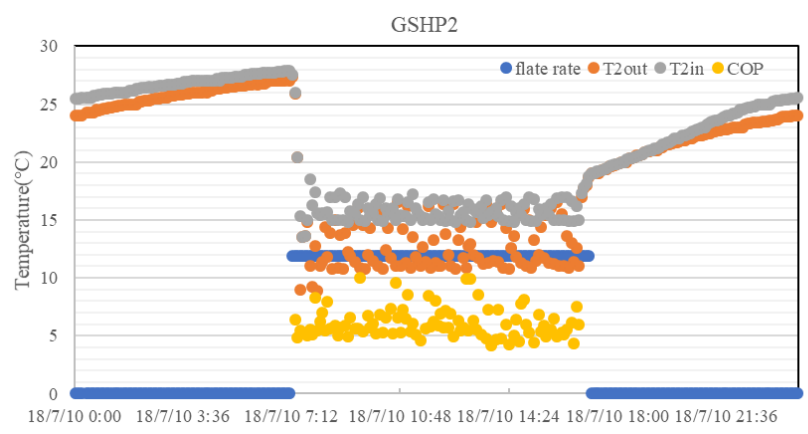

Fig. 6 Daily operation of GSHP2 on July $10^{\text {th }}$

Table 3. Energy consumption in Strategy 2

\begin{tabular}{|c|l|l|}
\hline Strategy2 & $\begin{array}{l}\text { Energy Consumption } \\
\text { Description }\end{array}$ & $\begin{array}{l}\text { Energy } \\
\text { Consumption } \\
(\mathrm{kWh})\end{array}$ \\
\hline GSHP1 & EHP1+EPHP1-1+EPHP1-2 & 84.21 \\
\hline GSHP2 & EHP2 $_{\text {EPHP2-1 }}+$ EPHP2-2 $_{2}$ & 97.77 \\
\hline
\end{tabular}

\subsection{Strategy 3}

In this strategy, absorption chiller works for $1^{\text {st }}$ and $4^{\text {th }}$ floor's fresh system and $2^{\text {nd }}$ floor's room cooling, while GSHP2 unit works for the $3^{\text {rd }}$ floor's room and fresh air system. Operation on August $16^{\text {th }}$ is analysed and the system performance is indicated in figure 7 and 8 . Inlet and outlet water temperature is around 13.2 and $16.6^{\circ} \mathrm{C}$, resulting a temperature difference about $3.4{ }^{\circ} \mathrm{C}$. COP of the unit is very close to 1 and the water flow rate is mostly constant. 


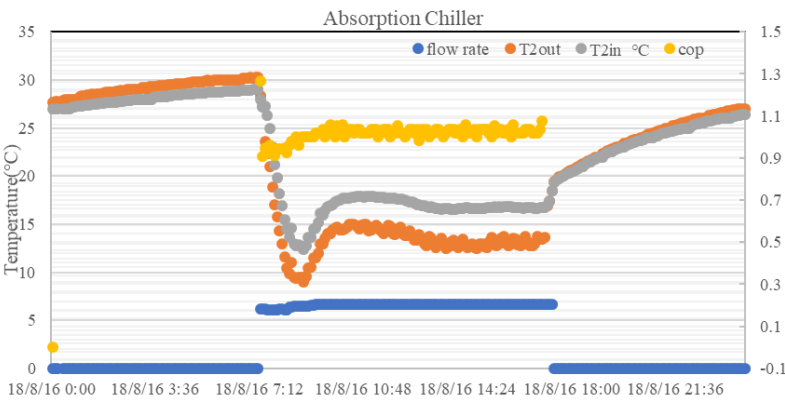

Fig. 7 Daily operation of Absorption Chiller on August $16^{\text {th }}$

Operation of GSHP2 is shown in figure 8 , in which inlet and outlet water temperature is around 12.3 and $16.2^{\circ} \mathrm{C}$ before 14:00, causing a temperature difference about $4^{\circ} \mathrm{C}$. Afterwards, outlet temperature rises to around $13.2^{\circ} \mathrm{C}$, and temperature difference decreases to $3^{\circ} \mathrm{C}$. Daily COP is about 6.1 .

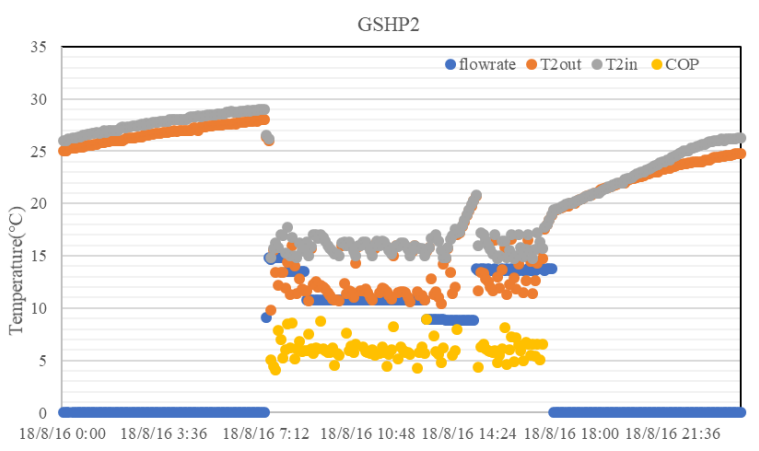

Fig.8 Daily operation of GSHP2 on August $16^{\text {th }}$

Table 4. Energy consumption in Strategy 3

\begin{tabular}{|c|c|c|}
\hline No. & $\begin{array}{c}\text { energy consumption } \\
\text { description }\end{array}$ & $\begin{array}{c}\text { energy } \\
\text { consumption } \\
(\mathrm{kWh})\end{array}$ \\
\hline AC & Ep $_{A C-1}+\mathrm{E}_{\mathrm{AC}-2}+\mathrm{E} \mathrm{p}_{\mathrm{AC}-3}$ & 102.41 \\
\hline GSHP2 & $\mathrm{E}_{\mathrm{HP} 2}+\mathrm{EPHP}_{\mathrm{P}-1}+\mathrm{E}_{\mathrm{PHP} 2-2}$ & 39.80 \\
\hline
\end{tabular}

\subsection{Strategy 4}

Strategy 4 is more complex than any other strategies. Cold water storage and direct cooling are utilized in this mode. If the system operates under this strategy, cold water storage operates first and then serves the building. Daily operation from night of 25th August to 27th August are in this mode. The system starts with the cold water made of Saturday night and stopped in the Sunday afternoon. GSHP 1 and absorption chiller are utilized in the cold-water storage. Then, cold water in the tank supplies the fresh air and room load for the 3rd floor the next Monday morning. Other chiller serves to other floors. Figure 9 and figure 10 show the working stations involved in this operation strategy.

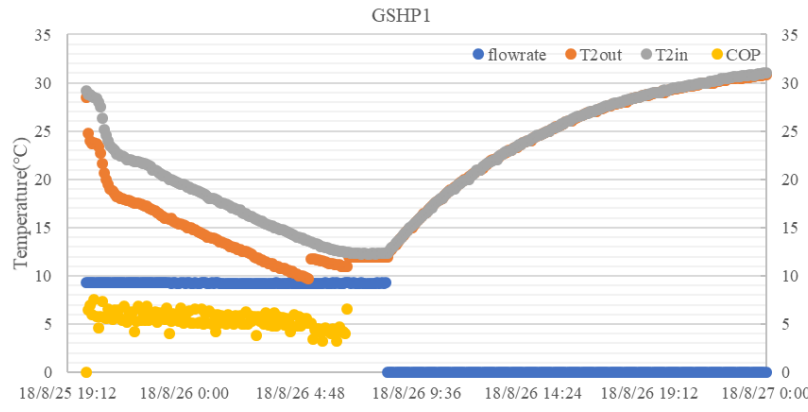

Fig. 9 Cold water making of GSHP1 on August $25^{\text {th }}$

Figure 9 shows cold storage procedure of GSHP1 unit, as the system starts at 20:00 on August 25th and stops at 8:00 on August 26th. GSHP1 works for 12 hours, and inlet and outlet water temperature are around 11.5 and $14.3^{\circ} \mathrm{C}$ respectively. Operation COP varies from 7 to 4.3 , showing an average of 5.4 .

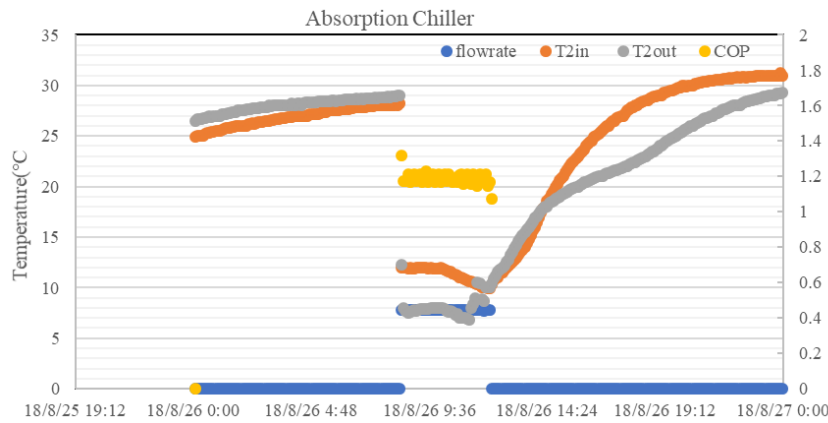

Fig. 10 Cold water making of absorption chiller on August $26^{\text {th }}$

Absorption chiller continues to make cold water for 4 hours after GSHP1 stops. Inlet and outlet water temperature is around 8.2 and $11.3{ }^{\circ} \mathrm{C}$, while the COP of absorption chiller is about 1.1. August $25^{\text {th }}$ and $26^{\text {th }}$ is a Saturday and a Sunday, so the absence of cooling requirement in the building means that the cold water is stored in the water tank until the Monday morning.

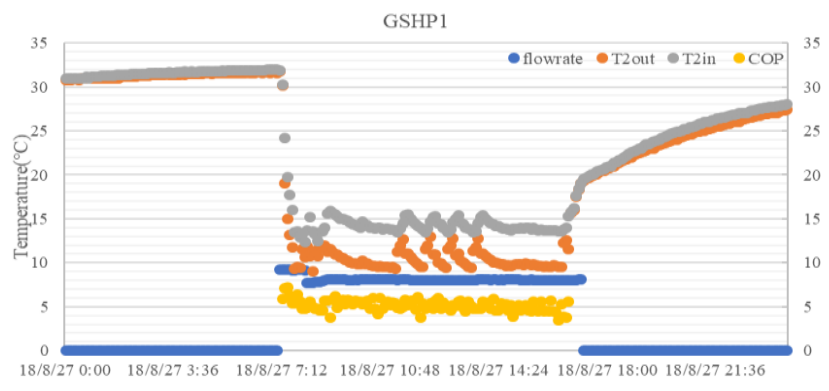

Fig. 11 Daily operation of GSHP1 on August $27^{\text {th }}$

On Monday morning, the system operates as usual. GSHP 1 works in mode 3 and provides fresh air load for the 1st and 4th floor and room cooling load for the 2nd floor. Daily performance of HP1 is indicated in figure 11 that inlet and outlet water temperature is around 12 and 13, leaving a temperature difference about $3.4^{\circ} \mathrm{C}$, while the $\mathrm{COP}$ is about 5.2. 


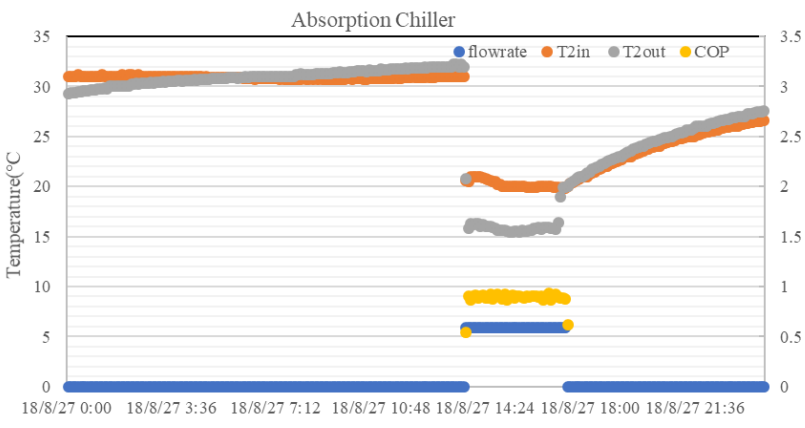

Fig. 12 Daily operation of Absorption Chiller on August 27 $7^{\text {th }}$

Cold water in the tank is utilized on the 3rd floor to provide room load and fresh air load. Absorption chiller continues when the water in the tank was not available. Inlet and outlet water temperature is around 15 and $20{ }^{\circ} \mathrm{C}$, leaving a temperature difference about 5 , while the COP of absorption chiller is about 0.92 .

Energy consumption of this mode is shown in table 5.

Table 5. Energy consumption in Strategy 5

\begin{tabular}{|c|l|c|}
\hline & $\begin{array}{l}\text { energy consumption } \\
\text { description }\end{array}$ & $\begin{array}{l}\text { energy } \\
\text { consumption }(\mathrm{kWh})\end{array}$ \\
\hline GSHP1 & $\mathrm{E}_{\mathrm{HP} 1}+\mathrm{EPHP1-1}_{\mathrm{P}}+\mathrm{EPHP}_{\mathrm{1}-2}$ & 236.52 \\
\hline $\mathrm{AC}$ & $\mathrm{Ep}_{\mathrm{AC}-1}+\mathrm{E} \mathrm{p}_{\mathrm{AC}-2}+\mathrm{E} \mathrm{p}_{\mathrm{AC}-3}$ & 33.60 \\
\hline
\end{tabular}

\section{Summary}

From the above analyse, we could easily find out the performance of the energy system under four different strategies. Energy consumption, COP of each system were shown in table. It is shown that strategy 1 has the lowest energy consumption, following by strategy 3,2 and 4. In Strategy 3, either AC or GSHP2 has a relatively better performance than other strategy. Either from energy consumption amount or system performance, strategy 4 seems like a bad choice. Energy storage itself consumes a lot of energy.

Table 6. Energy and Performance comparation of different

\begin{tabular}{|c|c|c|c|c|}
\hline Strategy & $\begin{array}{c}\text { Energy } \\
\text { Consumption }\end{array}$ & \multicolumn{3}{c|}{ COP } \\
\hline & $\mathrm{kWh}$ & GSHP1 & GSHP2 & AC \\
\hline 1 & 91.64 & 5.6 & & 0.65 \\
\hline 2 & 181.98 & 5.7 & 6.2 & \\
\hline 3 & 142.21 & & 6.1 & 1 \\
\hline 4 & 270.12 & 5.2 & & 1 \\
\hline
\end{tabular}

The above discussion is based on one day operation, more experimental should be done in each strategy, and analyse should be based on big data, then a relatively objective and valuable conclusion could be got.

\section{Acknowledgement}

This work is supported by National Key Research and Development Project of China No. 2017YFC0702600 (entitled :Technical System and Key Technology Development of Nearly zero enrgy building).

\section{References}

1. Huai Li, Wei Xu Zhen Yu et.al Application analyze of a ground source heat pump system in a nearly zero energy building in China, Energy, Volume 125, 15 April 2017, 140-151;

2. Zhang Shicong, et al. Operation performance in cooling mode of a ground source heat pump of a nearly zero energy building in the cold region China. Renew Energy 2016;87:1045-52.;

3. Huai Li, Wei $\mathrm{Xu}$ Zhen $\mathrm{Yu}$ et.al Discussion of a combined solar thermal and ground source heat pump system operation strategy for office heating, Energy and Building, 162(2018) 42-53; 